\title{
Kinship Idioms and Care-Control Dynamics in Hungarian Co- ethnic Philanthropy
}

\author{
Ildikó Zakariás ${ }^{1}$ (i)
}

Accepted: 14 January 2022 / Published online: 9 February 2022

(C) The Author(s) 2022

\begin{abstract}
The paper investigates processes and consequences of 'philanthropic kinning', that is the use of kinship and family idioms in constructing and maintaining personal relations between donors and recipients in philanthropy. Usual studies collapse the occurrence of kinship metaphors in philanthropy either as evidence of 'prosociality' (e.g. trust, care or love) or more frequently as evidence of 'paternalism' (power and domination of donors over recipients, and their objectification). This paper claims that introducing kinship and parenting studies into researching philanthropy would greatly refine our understanding of donor-recipient relations. In the framework of a qualitative case study of a philanthropic 'godparenthood' programme organised in Hungary supporting ethnic Hungarian communities in Romania, this paper looks at the roles, responsibilities and obligations various forms of philanthropic kinship offer for the participants; and relations of power unfolding in helping interactions. With such concerns, this paper complements earlier research on hybridisation of philanthropy, through its sectoral entanglements with kinship and family. Also, it contributes to research on inequalities in philanthropy, by showing how philanthropic kinning may recreate, modify or reshape donor-recipient power relations in diverse ways.
\end{abstract}

Keywords Philanthropy · Volunteering · Citizen aid . Interactions · Kinship · Family · Kinning · Parenting · Carecontrol $\cdot$ Power $\cdot$ Inequalities $\cdot$ Nationhood

Ildikó Zakariás

Zakarias.ildiko@tk.hu

1 Centre for Social Sciences, Institute for Minority Studies, Tóth Kálmán u. 4, Budapest 1097, Hungary

\section{Introduction}

This paper aims to inquire on processes and consequences of 'kinning' in philanthropy. While traditional conceptualisations of philanthropy depart from the assumption of distinguishing the 'civil' or 'voluntary' sector from private, kinship-based relations (and also from the market, and from the state), my research aims to investigate into the entanglements between these domains. More specifically, this paper, based on an in-depth qualitative case study of a specific philanthropic programme, is interested in processes whereby recipient-donor relations become perceived and interpreted in familial and kinship terms.

Usual studies collapse the occurrence of kinship idioms in philanthropy either as evidence of 'prosociality' (e.g. trust, care, love) or more frequently as 'paternalism', that is as evidence of power and domination of donors over recipients, and of their objectification. In this paper, I propose that kinship and family idioms and metaphors in philanthropy (and in related fields of volunteering, charity, citizen aid or grassroots humanitarianism) should be taken more seriously. Instead of simplifying and essentialising them either as indicating 'prosociality' or 'paternalism', family metaphors and related concepts, practices and emotions should be re-embedded into their socio-historical contexts.

Abstract ideals of helping distant others by means of philanthropy may be interwoven with various specific ideologies and ethical repertoires that enable the actual practical realisation of connecting with distant causes and individuals (Boltanski, 1999; Malkki, 2015; Dromi, 2021; author). Such ideologies-referred to as "moral frameworks' by sociological models of volunteer motivation (e.g. Wuthnow, 1991; Wilson and Musick, 2008, pp. 70-85)—define values, causes and aims to pursue, 
specify groups to support and point out proper practices, ways and tools of helping. Such ideologies in the background of helping have the capacity to ground philanthropic processes: they contextualise abstract helping intentions by naturalising donor-recipient connections, and offer identities, roles, activity repertoires that make the helping process comprehensible, worthy and legitimate for the participants (Wilson \& Musick, 2008, pp. 315-318, Oreg \& Appe, 2020; Dromi, 2021).

The broadest question of my research thus inquires on such moral frameworks, evoked by kinship idioms in philanthropic interactions. What kind of roles, identities, responsibilities and obligations do various kinship idioms offer for the participants of the helping process? How do these roles shape actual donor-recipient interactions and practices of helping? And ultimately, how do these moral frameworks shape ideologies of belonging, solidarity and helping that circulate beyond the helping interaction?

Such entanglements of kinship, philanthropy and ideologies and discourses of helping are analysed on a specific terrain, that of philanthropic programmes built upon ideologies of national solidarity, organised from Hungary, and directed towards supporting ethnic Hungarian children, their families and their communities in Romania. The analysis is based on ethnographic research conducted in one such programme: a child sponsorship network designed along the idiom of 'godparenthood', aiming to support Hungarian-speaking children and families in Moldavian Csángó villages in Romania.

On this specific empirical terrain, the paper will show that by no means may such philanthropic kinship relations be treated as homogeneous and universal; on the contrary, precisely this multifaceted nature and flexibility of family concepts allow for the operation and long-term maintenance of such philanthropic aid often bridging large socioeconomic distances.

In this vein, this paper aims to further earlier research on 'hybridisation' mechanisms in philanthropy by complementing recent scholarly focus on its sectoral entanglements. While recent research has already pointed out the significance of the state and the market in such hybridisation phenomena (Shachar et al., 2019; Lichtermann \& Eliasoph, 2014), this paper foregrounds the entanglements of philanthropy with the fourth domain, that is with kinship and private familial relationships.

Also, concern for the entanglements between philanthropy and private relations of kinship contributes to a relatively neglected topic in the research of philanthropy, and the related fields of volunteering and civic aid: that of donor-recipient inequalities (Grubb, 2021; Carlsen et al., 2020). This paper will show that kinship relations in the institutional context of philanthropy may become powerful mediators, which may recreate, modify or reshape donor- recipient hierarchies and related care-control dynamics in diverse ways.

\section{Kinship Idioms in Philanthropy Research}

Although the term 'kinning', invented by Howell (2006), was initially applied to describe the building of parentchild relations in processes of transnational adoption, suggestions have also been made to broaden these explorations to other terrains (Thelen et al., 2014; Thelen, 2015; Rebollo et al., 2018). As for philanthropy, various ethnographic, anthropological and sociological studies focus on the possible enhanced role of personal relations between donors and recipients of help (for an overview of the topic: Fechter, 2019). Among these several authors have taken notice of the working of kinship and familial idioms and metaphors in the construction of personal donor-recipient relationships: in case of international development and humanitarian child-sponsorship (Bornstein, 2001, 2012; Drążkiewicz, 2020; Fechter, 2019; Noh, 2019; Rabbitts, 2012; Zarzycka, 2016; Zakariás \& Feischmidt, 2020), in personal mentoring schemes of disadvantaged students built upon volunteering in educational and welfare settings (Molpeceres et al., 2012), in a historical account of donor identity formation by the Red Cross (Dromi, 2021), and more recently in personalised helping and mentoring of refugee minors residing in Western European countries (Raithelhuber, 2019; Scheibelhofer, 2019; Aflaki \& Freise, 2019).

In her seminal work on humanitarianism in urban India, Bornstein (2012, Ch. 5) reveals how giving outside one's own biological family may become endowed with kinship idioms. Conceiving recipients of support in familial terms makes such support socially meaningful in social contexts where care and concern for others is primarily and dominantly linked to care for the own kin. Such relationality is shown to enable long-term personal connections, responsibilities and obligations, and is contrasted by Bornstein with more impersonal and temporary forms of humanitarianism. Analysing religious-based child-sponsorship initiated from the UK towards non-Western countries, Frances Rabbitts highlights how donor-recipient relations may be conceived of as analogous to familial (especially parental) connections, which contributes to shape such charitable and humanitarian relations 'providing contextual environments within which charity is situated and understood' (see also Molpeceres et al., 2012). While developing her ideas on the role of the 'desire for connection' in humanitarian and charity processes Anne-Meike Fechter (2019) alludes to the enhanced role of familial, kinship idioms and metaphors in creating donor-recipient relations. She emphasises the potential of such kinship metaphors in 
naturalising connections and specifically helping relations between strangers, distant according to socio-economic positions or cultural-geographical imaginaries.

The above authors and research perspectives understand familial and kinship idioms as facilitating connections between strangers, and emphasise their capacity to induce relations of care. Another major scholarly focus on familial metaphors-not entirely distinct from the earlier-regard familial metaphors as evidence of power and domination. Critical research on child-sponsorship and mentoring echoes a more general critique of philanthropy, humanitarianism and development on the reproduction of donorrecipient power relations subordinating the latter in various ways (Grubb, 2021; Rabbitts, 2012; Zarzycka, 2016). Postcolonial and feminist critiques of philanthropy and humanitarianism (e.g. Burman, 1994; Manzo, 2008; Sinervo \& Cheney, 2019; Suski, 2009; Holzberg, 2019) discuss the role of kinship idioms in its specific form of 'paternalism', claiming that oppressive parental desires and imaginaries lie behind support directed towards the 'ThirdWorld'. According to such critiques, these organisations and programmes, often building upon the historically developed Western image of the vulnerable and innocent child decontextualise the helping process, disregard the local knowledges and perspectives of targeted individuals and communities, ultimately rendering recipients voicelessness and passivity.

This paper claims that while thoroughly elaborating core characteristics and potentialities of such organisations and practices, both of these approaches carry the risks of essentialising and decontextualising the concepts of 'family' and 'kinship'. As they often fail to pose the question 'what kind of kinship? What kind of family?' these perspectives may sometimes overlook important consequences of the use of such metaphors on philanthropic relations. Anthropological and sociological studies of kinship and parenting revealed the multiplicity of forms of familial relations, and revealed that these might be associated with diverse practices, concepts and emotions, and diverse configurations of power. Such studies, mostly related to the field of governmentality, have shown how parental roles, responsibilities and emotional repertoires have shifted throughout various socio-historical contexts; and depending on socio-political, legal and institutional circumstances, how these developed into multiple forms. (Burman, 2016; Faircloth, 2014; Rose, 1999).

We have no reason to assume that family idioms evoked in the institutional context of philanthropy do not show similar variability. Based on ethnographic research carried out in a particular philanthropic setting, this paper explores how 'everyday' understandings of familiarity described by scholarly studies on kinship and parenting shape donorrecipient philanthropic relations, and specifically, relations of care and control. Before immersing into empirical analysis, however, a brief description on the social context and the applied methodology is necessary, that form the topics of the next sections.

\section{The Research Context and Methodology}

\section{The Godparent Programme Supporting Hungarian Language Education in Moldavian Villages}

The analysis will be based on a qualitative case study of a child sponsorship programme designed to support Hungarian-speaking schools, students and teachers among Moldavian Csángós in Romania. The 'Godparent programme' ${ }^{1}$ founded in 2007 aims to support Hungarian language education in Csángó villages in Moldavia, Romania, inhabitants of whom are considered by national discourses in Hungary as part of the historical Hungarian nation. The programme resonates with national ideologies and discourses that regard ethnic Hungarian minorities of Slovakia, Ukraine, Romania and Serbia as bearers of a national authenticity, under constant threat of assimilation on the part of majority societies. Based on this discourse, these minority groups need the help of the kin-state (Hungary) and its population in maintaining the Hungarian national culture and resisting assimilation (Feischmidt, 2005).

The outlined discursive field is in great part produced and maintained by assistance policies of the Hungarian state, which stretch over the classic terrain of state responsibilities that is the community of citizens (Bárdi, 2013). The helping discourse, however, operates in spheres outside the state as well: private individuals and formal or informal voluntary associations are implicated in its use (Zakariás, 2015, 2019). Large philanthropic organisations, such as the Hungarian Red Cross, often have their specific division or programmes directed towards Hungarian minority communities in neighbouring states, and there is a multitude of smaller associations, family, church, workplace communities that organise such support. ${ }^{2}$

\footnotetext{
${ }^{1}$ The programme and individual interlocutors in the article are pseudonymous

2 National solidarity as an ideological framework of these transnational philanthropic aid initiatives renders them to some extent analogous to diaspora philanthropy, in that giving, volunteering and donating are closely connected to the assumed sameness of donors and recipients regarding ancestral ties and belonging to an imagined homeland and ethnic, national or regional community (for a recent review on the term see Appe \&Oreg 2020, Flanigan 2017). The academic use of this concept, however, dominantly implies a development policy and philanthropic management research perspective, and much less a constructivist-interpretative analytical
} 
The programme in the focus of this paper, a representative of these philanthropic initiatives built upon the discourse of national solidarity, seeks donations for Hungarian language education in Moldavian Csángó settlements, mainly villages, by establishing a long-term familial-type relationship between the donor and recipient: the former becomes the symbolic godparent of a Csángó child, the relationship being maintained through letters, gifts, and trips between Hungary and Moldavia. Less active godparents may restrain their activities to paying a certain sum of money to support Hungarian language education; however, godparents are also expected to pay visits in summer camps organised for these children in Hungary, or directly in their home villages in Moldavia (see also Bodó \& Zabolai, 2016)

The programme is closely connected to Hungarian language teaching in Moldavian Csángó villages. Hungarian language classes, after being closed by the Romanian education authorities in the 1950s, have been gradually relaunched since the 1990s. Their reopening was initiated by a civic movement born after the transition animated by local and Transylvanian intellectuals and activists, whom within the framework of the ideology of national survival and the discourse of minority rights started lobbying both at the Romanian and Hungarian government for providing legal and financial means of education in the 'mother tongue' of the local Csángó population. The last two decades brought a relative accommodation of the Hungarian language education, from the initial position of extracurricular activities and third-sector institutions, into the Romanian state-recognised public educational system (Laihonen et al., 2020). Besides the Romanian state, subsidising public school classes and teachers in the programme, also the Hungarian government and philanthropic donors (and among them 'godparents') from Hungary and Transylvania provide important financial support for the extracurricular parts of the programme, as well as the maintenance and living costs of Hungarian language teachers recruited from Transylvania and Hungary. Today, these classes are present in about 30 villages of the region and reach about 2000 children, employ about 60 teachers (Laihonen et al., 2020), while donors of 'godparent' status varied between 800 and 250 .

The most important declared aim of the godparent programme is to provide a financial pillar for the Hungarian language teaching in Moldavian villages. In addition to being a practical channel for financial donations, personal attachments are emphasised in the programme mission as a possibility for obtaining deep personal contacts,

Footnote 2 continued perspective characterising this current paper (see Appe \&Oreg 2020, Lainer-Vos 2014 for exceptions). and a possibility for experiential learning about a traditional (national) community, and authentic (national) ways of life. Prospective godparents are paired with potential children by Hungarian language teachers. According to advertising texts and descriptions, those who are interested in and committed to these goals, may 'receive' a godchild through the programme. As simple as such phrasing suggests, the actual establishment and maintenance of such relations is an intricate process we shall examine in the following, after a brief summary of the applied methods.

\section{Methodological Considerations}

The research focus on personal relationships and donorrecipient interactions and the transnational character of the analysed philanthropic programme required that I carry out multi-sited ethnographic research (Marcus, 1995). I followed donors and recipients in their encounters in various geographical and institutional spaces: in Hungary and Romania, on journeys while travelling, in NGO spaces and private homes, as well as in offline encounters and in online spaces. The goal behind my choices of data collection has been to track the flow and connections of persons and objects that build up this philanthropic assemblage and that enable diverse forms of interactions between donors/volunteers of the programme and the recipients of support. This multi-sited interactionist approach leads to participant observation of encounters between the helpers and the helped, that took place in a summer camp in Hungary, during three one-week long trips with godparents to Moldovan villages, as well as in ten one-day associational events in Budapest. Also, around 20 semi-structured lifeworld interviews (Kvale, 1996) with active participants (12 interviews with godparents, 7 with godchildren and their parents, and one with a Hungarian language teacher in Moldova) were carried out between 2009 and 2015. The interviews, lasting $1.5 \mathrm{~h}$ in average, started with a narrative biographic account of becoming involved in the programme, which was followed by a more structured part inquiring about knowledge on helping interactions, practices and positive and negative past experience, about future aims and plans, and in case of stakeholders, about the history, mission, structure of the programme. Besides interviews, detailed field notes on interactions have also been kept in a field diary, covering talks and discussions as well as emotions, bodily gestures and practices. I also gathered online media content: the homepage of the association formed around philanthropic godparenthood provided a rich database on official documents and mission statements, media publications, descriptions of numerous associational events, as well as personal godparent testimonials in written and video formats. 
The 20 interviews, as well as relevant video material (altogether 18 personal testimonials), have all been transcribed verbatim, and together with fieldnotes and downloaded texts from the association's homepage were subjected to multiple forms of analysis. Semi-structured lifeworld interviews were analysed in line with five steps of analysis by Kvale (1996, ch. 11), and individual case studies were then constructed on personal motivations and experience of helping interactions. Such individual accounts were contextualised with fieldnotes obtained from participant observations of donor-recipient interactions. Interpretations and meanings on the institutional level have been derived from analysing organisational documents as well as textual and video material from the homepage of the godparents' association, with a social constructivist hermeneutic approach (Schwabenland, 2006). All of these analytical tools contributed to build up an in-depth qualitative case study as in Yin (2014), aimed at describing complex processes of relatively bounded phenomena with the perspectives of deriving also generalisable conclusions, relevant for broader theoretical discussions. The dominant language of communication throughout my research has been Hungarian, however, to a much smaller extent, my basic command of Romanian has also been used.

Compared to most studies focusing on familial metaphors and 'kinning' in philanthropy (or in related fields of volunteering, citizen aid or humanitarianism), the analysed programme might seem peculiar because of its ideological framework, centred around the idea of nationhood and national cultural survival. Readers may challenge the generalisability of the results of such a specific form of philanthropy, based on an explicitly particularistic ideology, and its relevance to phenomena usually conceptualised as based on universalist concepts of poverty alleviation or humanitarianism. Against these challenges this paper claims that studies of philanthropy, charity, or humanitarianism have recently explored potential particularistic roots of various allegedly universalist initiatives, and questioned clear-cut divides and boundaries between them (for example Malkki, 2015; Drazkiewicz, 2020; Zakariás \& Feischmidt, 2020). These scholarly works have revealed that, instead of defining distinct types of philanthropic support, various conceptual frameworks and ideologies-particularistic as well as universalist-are rather layered upon each other and may simultaneously, in concert provide the moral foundations of giving and helping.

The choice of this specific programme for this paper was thus not primarily lead by an interest in philanthropy based on national ideologies. Rather, it was selected out of methodological considerations of some sort: as shown below, it represents a case where donors' and recipients' ideas on the proper helping diverge, that is donors' and volunteers' conceptualisation of proper aid in many instances clearly and explicitly differ from recipients' ideas on support they would prefer to receive. Such clear dissensus on the ideal content and form of helping, to be outlined in the following sections, facilitates the unearthing of philanthropic donor-recipient power relationships and its epistemic consequences and renders it easier to empirically ground and illustrate the analytical claims of the paper.

\section{Kinship, Nationhood and the Possibility of Connection}

In organisational-institutional representations such as the homepage of the association, or formal speeches in official celebrations, idioms and metaphors related to family and kinship prevail in abundance. The following extract from a video-testimony of a godparent exhibited on the webpage of the programme illustrates well such abundance of connotations and meanings connecting nationhood and kinship on various levels.

(...) Why are Moldovan Hungarians so respectable?

Because of their existence, their faith, their survival.

Orphans of our nation, they have preserved their ancestral faith with great fidelity for centuries. (...) I also respect that they have big families, with many children, and many of them aspire to teach their ancestors' language, traditions, find their historical roots, and share it with their offspring. (...)

Familial parent-child metaphors unite ethnic Hungarian minority communities and the Hungarian state: Moldavian Csángós are 'orphans of the nation'. Also, the Hungarian nation is imagined as strengthened by relegating Moldavian Csángó families to the national body, the latter representing national authenticity through their authentic (national) traditions and values. Such ideas easily resonate and slip into each other, connecting kinship and nationhood on various scales.

As described by Anderson, the modern nationalist sentiment and an abstract solidarity towards co-nationals are partly implied by the public use of a metaphoric language on the nation as an imagined family. ${ }^{3}$ In line with this proposition, in the philanthropic programme explored in this paper the idiom of kinship resonates well with explicit and implicit intentions and desires related to nationhood

\footnotetext{
3 Researchers in the last decades have revealed how imaginations of nationhood and national belonging and ideal models of family and kinship mutually inform each other. Nation-as-family metaphors and reference of familial norms may shape perceptions of governmentcitizen (power) relations (Lakoff 1995), moral relations in everyday public encounters (Shirinian 2018), and narratives of inclusion and exclusion in transnational adoption (Garcia Gonzales 2015).
} 
and authenticity. Such abundance of familial tropes allows for closing the conceptual distance between the abstract goals of philanthropic support and creating actual donorrecipient relations. All these concepts, then, elicit and legitimise personal godparent-godchild relationships in practice, in their actuality.

Such mental operation, however, is much more difficult on the side of the recipients of philanthropic support. On my first trip to Moldavia, in 2009 I was accompanying a group of friends, all around thirty years old. Three of them already had godchildren in a Moldavian village, while two persons were considering of becoming godparents. During our journey, one of them, Peti finally decided to engage himself.

Together with the local Hungarian teacher they visited a family, where the teacher announced that one of the boys may become the godson of Peti. After the teacher had left, the father started to interrogate in a hostile tone about Peti's real intentions and motives in becoming a godfather in Moldavia. Peti got really embarrassed, remained deeply puzzled by the ambivalent reception of his good will. (quote from my field-diary)

In order to better discern this uneasy encounter, we must consider the local socio-historical context of the programme. In Csángó communities, assimilation processes are under way, referred to by ethnographers and linguists as language-shift, language-change, and identity change (Peti \& Tánczos, 2012). This makes the ideology of Hungarian national preservation hard to identify with for many Csángó habitants in Moldavian villages. Donor perspectives are conceptually setting heroic minority resistance of the Csángós against the assimilationist state of Romania. However, Hungarian national curriculum (Hungarian national history, geography, literature etc.) has not been taught in the second half of the twentieth century in these villages, and local Romanian state institutions, such as public administration or education were explicitly hostile with the use of Hungarian language, and with evoking Hungarian national discourse and narratives (Laihonen et al., 2020). Related to that, strategies of social mobility (education, employment) became closely tied to the Romanian state and its majority language institutions, and to ethnically heterogeneous networks of labour migration towards Western Europe. Therefore, the idea of (Hungarian) national unity and the ideology of (Hungarian) national preservation is often missing from the local social imagination; just as acquaintance and habitual embodiment of roles and 'language-plays' (Eriksen, 1991) prescribed by these ideologies, such as a 'heartfelt need' to speak one's mother tongue, a strong dedication to Hungarian language education and religious services, or performing folkloric customs as part of identity politics. Moreover, in the local social imagination, as modernisation and social mobility is associated with Romanian language use and Romanian identification, Csángó-ness and Hungarian language use is often attributed with underdevelopment and ultimately, poverty. (Peti, 2011).

Such processes of language change and assimilation results that the broader goals of the ideology of 'Hungarian national preservation' remain distant and may even become denigrating for the recipients of support. Among such circumstances, the idea of philanthropic support arriving from Hungarian donors and volunteers, based on this ideology of national survival, is mostly illegible - as illustrated by the above extract from my research diary. The stakes of kinship metaphors here become much greater than just contextualising, as for the Hungarian donors and volunteers, the somewhat abstract goals of national solidarity. The idiom of kinship, and specifically godparenthood-recorded by ethnographers and anthropologists as central in Csángó lifeworlds (Timaru, 2020)_enables that the connection and helping relations may become socially meaningful for communities and individuals unfamiliar with the idea of national philanthropy.

On my visit to a Moldavian village in Autumn 2010, I met Kati, the mother of a local schoolgirl. Kati tried to obtain information about the (philanthropic) godparents of her daughter, living in Budapest, and complained that although her daughter had spent numerous letters yearly to her godparents, the latter never answered. Kati explained the image of the philanthropic godparent programme likening their role to 'everyday' forms of godparenthood that link members of the local community:

They [the villagers] take it [the godparenthood in the programme] as a good thing! They [the godparents] are just like in our village, whom baptise [the children]. They feel good about them [the godparents]!

They are like, like an angel, a protective angel, that's how they feel about them. That's how I understood, those who really have [godparents from Hungary].

That finally, they have arrived.

Besides bridging - albeit unevenly-diverging understandings of national ideologies of donors and potential recipients, godparental relations are also addressed to mediate differences of socio-economic positions among donors and recipients. The initiators of the programme, volunteers and godparents are middle-class health, education, cultural professionals, entrepreneurs, managers all being able to afford to participate in the programme. They have the financial means to offer donations, they have free time to do fund-raising and voluntary work, they have the material means and free time to offer accommodation in their homes, and to travel to great distances to visit the 
supported communities in their settlements. The majority of the recipients of support are less wealthy, less educated, often having finished only primary education, living in economically depressed rural areas in Moldavia, Romania. The majority of adults work in agriculture or on the secondary labour market, being able to afford large distance travels only as part of their labour migration to Western Europe.

Personal familial relations among such conditions require careful arrangements and intricate processes managed and organised through collective and individual institutional practices on the part of 'relationship brokers' (Fechter, 2020), that is volunteers and Hungarian language teachers residing in these villages. While mediation and brokering plays a central role in enabling the travelling of persons and objects through great social, geographic and physical distances, and contribute to the flow of knowledge and resources through complex trajectories, the organisation of the programme also allows for the deployment and proliferation of spaces of more direct personal encounters and interactions between donors and recipients. Godchildren and their siblings may be invited to godparents' homes in Hungary to spend some holiday time there (usually a few days) and godparents may also visit their godchildren in summer camps in Hungary or even in their homes in Moldavia. Also, godparents may keep direct contact with their godchildren and their families by phone. Ágnes and Tamás, a couple in their forties, living in Budapest, enthusiastically recalled their encounter with their goddaughter Regina as follows:

Tamás: And then Regina had arrived to our lives, entirely by chance...

Ágnes: ... and she wrote us letters...

$\mathrm{T}$ : ... and we exchanged some letters from time to time, not too often, and I also paid this sum of money. And then we went [to the summer camp in Hungary]...

Á: ...that was the first personal encounter, because she [Regina] spent a week there, and...

$\mathrm{T}$ : ...well, that was indeed cathartic...

Á:... because I thought poor little girl, how embarrassed she would be, but nothing like that (...) and it was incredibly astonishing, this encounter, because this child, she was so hugging, she kept hugging and kissing us, she was holding my hand all the time. We were playing in the lake...

$\mathrm{T}$ : ...we were playing balls...

Á: ...So the entire day, we were together, as if she was our own child. She was so hugging, she was wonderful, it was unbelievable (...)

As this extract illustrates, direct communication creates social spaces where donors and recipients evade institutional settings of education and civic organisation. They remain among themselves-and such privacy enables them to translate metaphoric kinship, initially controlled and reproduced by intermediary institutional actors, into everyday meanings and practices.

\section{Parenting Scripts and Care-Control Dynamics}

A custom cultivated in various regions in Central and Eastern Europe as related to baptism of newborn children, godparenthood belongs to the realm of 'chosen kinship'. Godparents, either invited by family members, or offering themselves their support, become mandated with long lasting responsibilities and obligations both towards the godchildren and towards their parents. Godparenthood is also attributed with power-godparents becoming entitled to interfere with essential decisions around the fate of godchildren (Timaru, 2020; Vasile et al., 2018). Such godparental responsibilities become evoked also in philanthropic donor-recipient relations. Three major "cultural scripts' of parenting (Faircloth, 2014) may be found in godparental relations in the explored philanthropic programme: (1) parental responsibilities of national socialisation are complemented with (2) a focus on achieving education and development, and (3) with bringing fun, joy to the recipients, and thus building intimacy and closeness with them through popular consumption.

\section{National Socialisation as (God)parental Responsibility}

The primary aims of the philanthropic programme of preserving national identity and culture may be aligned with (god)parental responsibilities of donors and volunteers. Disciplining along the ideology of national preservation is characteristic of events and activities organised by volunteers of the programme for the Moldavian kids. I have described elsewhere (Zakariás, 2019) that such disciplinary regards may consist of gestures and expressions of 'ethnic scolding' that is inviting, suggesting, or sometimes ordering, with various emotional intensity and pressure, specific behaviour related to Hungarianness. Such ethnic scolding implies requests towards children to perform national identity and culture: wear folk costumes, participate in folkloric cultural events, choose Hungarian language secondary and tertiary education, perform aspirations for the role of the 'minority intellectual', and most and foremost, speak Hungarian. Godparents may attempt to pursue such goals of national socialisation of kids. Others have described (Yuval-Davis, 2005) that duties of national socialisation in Western societies are assigned, among other institutions, also to familial contexts, and specifically 
to female carers in the family. As explored in detail by Bodó \& Zabolai (2016) for the case of Hungarian language socialisation in these godparental relations, such duties of national socialisation may thus become part of the intentions, dispositions and actions of godparents, not only as part of their civic commitment, but also as implied by their roles and duties as kin. The following vignette, taken from my research diary, exemplifies such interactional dynamics of godparents visiting their godchildren and their families in their homes.

We arrive to the house of Emilia, the goddaughter of Balázs and Lili, a couple in their late 20 s from Budapest, with a university degree in economics. They greet the mother of Emilia, who after showing us around the garden and animals, invites us in. In the house a richly set table awaits us with lunch: chicken and salad. Balázs and Lili hand over a parcel to Emilia with full of chocolate and a book. Emilia takes it with a neutral facial expression, embarrassed, and puts it aside without a word. She starts to open it only after explicit requests from Lili to do so. Lili and Balázs immediately start to inquire on Hungarian language classes in the village, on the frequency Emilia attends these, and ask Emilia if she would say a few sentences in Hungarian. Emilia's mother gets embarrassed, and starts to talk about her own anxiety and her worries regarding their Hungarian language use. She then starts to explain why children in the village and in their family, including Emilia prefer to use Romanian in everyday life. Emilia herself, earlier already expressing reluctance to attend our gathering, and joining us only after her mother's scolding, at this point expresses her frustration and leaves the room not to come back at all during our visit.

Such invitations, requests, offers, suggestions are mostly accepted by Csángó kids as legitimate when expressed by Hungarian language teachers participating in the philanthropic programme. However, as seen in the vignette above, when evoked in godparent-godchild private interactions these are often accompanied by deep frustration. Annoyance, disappointment and shame may ensue, and emotional distance on the part of godchildren, all of which usually imply reluctance to engage in further interactions.

\section{Supporting Education and Personal Development}

Disciplinary attempts to regulate 'proper' behaviour of kids may not be restricted, however, to the domain of national socialisation. Numerous godparents may feel entitled to exercise some form of pressure to orient their godchildren towards the 'betterment of their destiny' through education. Critical feminist studies on parental roles in Western societies point out the growing expectations on parents (both middle class and in lower classes), throughout the twentieth century, to socialise children to comply with the state and its educational institutions (Allen, 2005, 11-12 p., Burman, 2016; Rose, 1999; in Hungarian context Kovai 2016). Recent research on cultures of parenting also draws attention to discourses of parents playing a central role in assuring education and future employability of children. (Fretwell, 2020; Lee et al. 2014; also in the Hungarian context: Szőke 2020).

Such preoccupations with education also prevail in the explored philanthropic programme. While centred around younger kids in primary schools, it also offers scholarships, student hall accommodation and mentoring for secondary and higher education pupils in schools operating in Hungarian language in Transylvania or Hungary (Bodó \& Lajos, 2020). The official philanthropic mission of the programme primarily regards education of these children as a means of preserving the Hungarian language, culture and the Hungarian community in these settlements. Many godparents, however, become intensely preoccupied with education in a broader sense-irrespectively of the language of studying, be it in Hungarian or Romanian.

Gifting often reflect such concerns, as in the accounts of Ágnes and Tamás:

(...) Primarily we bring them school equipments, that's our first question to ask. Do you have a proper schoolbag? Does it still work, the one from the previous year? Then let's see the exercise books, pens, pencils, rubber gums, bow compass, ruler! We crossquestion it, what do they have already, what is still missing (...).

Zsuzsanna also reveals strong commitments towards the schooling of her godchildren. Beyond organising associational life for godparents, fundraising and children camps, she also deeply engages herself in supporting her goddaughters: sent letters and parcels to them, frequently called by phone and paid visits in Moldavia. At one such occasion, she was shocked to find out upon arrival that after three years of studies in a (Romanian language) secondary vocational school, her older goddaughter had eloped to Italy with his boyfriend. Zsuzsanna considered the elopement with parental anxiety and paralysed desperation, fearing prostitution and being disappointed for the school dropout of her goddaughter.

She was so intelligent, the second best in her class, and she needed only two more years for her vocational degree. I supported her financially for many years, and we hosted her, such a beautiful girl. (...) I was so worried about her. I thought maybe I could bring change to someone's life. (...) And I always tell 
to her little sister, that she has to study, because that's the only way out of poverty.

While godparents' disciplining attempts in the framework of Hungarian national socialisation is often met with frustration and even hostility, the goal of obtaining education and/or vocation for children is more legitimate also for godchildren's parents and larger families, and often, for the godchildren themselves.

\section{Bringing Joy Through Popular Consumption}

The previous two subsections explored how godparents attempt to shape subjectivities of their godchildren in line with parental preoccupations, first, with Hungarian national socialisation, and second, with education. Such attempts to impose norms, values, habits upon kids are based on intentional or habitual convictions about the public good and the betterment of society that are based on knowledge external to godchildren's ideas and perspectives. However, such quasi-parental roles may also mobilise a third script of parenting. Godparents perceive and understand their duties as caring for their godchildren in the sense of being attuned to their physical and emotional needs, reducing their perceived suffering, and providing them with 'fun' and enjoyment, and emotional security and closeness.

These dispositions resonate with specific parental obligations and responsibilities to dedicate themselves to their children, described by others as expectations towards primary carers of children-mainly mothers-increasing in the European context since the mid-twentieth century (Allen, 2005; Lawler, 1999; Zelizer, 1985). Such parental caring dispositions and quest for intimacy and closeness imply that children's needs become formed, expressed or defined primarily by children themselves: expressed verbally, in forms of explicit claims, or on the level of embodiment and bodily gestures.

In the explored programme, godparents carry out their philanthropic activities in line with such parental obligations, a dominant state of emotion being a sensitivity, attunement and focus on godchildren, in order to find out, inquire on, understand and ultimately, fulfil their desires. Just like in everyday parenting in middle-class Western families (Brusdal \& Frønes, 2013), gift-giving and organising leisure activities for the children often reflect such states of attunement and care in our terrain as well. Typical gifts intended to serve the goals of national socialisation are books part of the national literary canon in Hungary, or leisure activities connected to cultural heritage places of the Hungarian national history. Gifts principally connected to education are often linked to school equipment, as seen in the previous subsection. In this third mode of parenting, however, besides the above activities, popular consumption also may become central. Toys, good quality clothing, photo machines, mobile phones are bought or sent to godchildren, and leisure activities are organised such as going to the circus, to swimming pools and to playhouses. Such popular consumption activities provide a major terrain for children to express their desires and to formulate requests towards their godparents. The following account arriving from Ágnes and Tamás reveals how implicit expressions of godchildren's desires, in this case Regina's, may become deciphered through attentive godparental regards:

Ágnes: We bought a mobile phone for Regina. She wanted it so hard, she even said his father had given her money for that, which was surely fictitious, but I guess she intended to show us how much she wished for a mobile phone, and...

Tamás: ... but she has never asked for anything... Á: Never!

T: So it was not like she was using us... But this mobile phone, it must have been an incredibly huge thing for her. And then we went to our usual shopping, to buy some clothes for her, and we could sense then that a mobile meant everything for her....

In the following extract, we see how norms of giftgiving in the family-though modified by the social imaginary of poverty in the context of philanthropy-become referents for gifting in the godparent-godchild relationship, ultimately lead by desires and wishes of the recipients of support. As godfather László described:

We went together to the [supermarket], and the little girl, my goddaughter, grabbed a pair of shoes, a sandal, and some more pieces of garments. Had I been with my own children or grandchildren, I would have slapped to their hands at this point already, but then, I thought, at last, I am able to pay for it, and for her, this might be the first time in her life, such a situation.

Gergely, a middle-aged engineer, CEO of a company in Budapest, often visits regions outside Hungary, frequently connecting business and philanthropic purposes. Just like for many wealthier volunteers and donors, gifting is in the centre of his philanthropic activities.

G: (...) What is interesting, unusual for us, is that he [my godson] expresses very directly what he would like to do or to have. 'My dear Godfather, please send me' this or that. (...).

Q: And what is he usually asking for?

G: It's hard to remember, what was it, yeah, last time he got a photo machine for Christmas. Firstly, if he learns well how to take pictures, this [skill] might 
even develop into a profession. (...) And possibly, there is printer at school, they can print the photos. (...) Other times he asked for fashionable kids books, once he asked for LEGO, these are like, I read it [the request] and if I can and approve it, I try to send it, if not, then nothing happens.

This quote illustrates well various phenomena that stretch over simplistic ideas on donor domination over recipients, but also on simplistic ideas of universal altruism. Just like in parent-child relations, Gergely aims to fulfil desires of his godchild, in order to bring him joy by providing him with consumption goods he cannot afford, but he openly asks for. In parallel, we also see Gergely filtering such requests according to his own ideas and values; and also his attempts to reinterpret the desired consumption goods as more legitimate according to his middle-class parenting values, as meaningful in the framework of personal cognitive development, education and potential future employment of godchildren.

\section{Reshaping Donor Perspectives Beyond the Helping Interactions}

The previous subchapters explored how philanthropic kinning based on idioms of godparenthood mobilised various parenting scripts, some of which converging with, while others diverging from the main ideological framework of the programme, that is the ideology of national preservation. These findings also revealed how specific parenting modes allowed donors and volunteers to acknowledge recipient perspectives, and to accept their preferences and choices, even if divergent from the official philanthropic mission. Not only practices of gifting or of leisure activities in personal donor-recipient encounters may become altered by such parenting perspectives, however. Firstly, the temporal horizon of philanthropic donorrecipient relations may change profoundly. While the mission of the programme implies a conditionality for participation in line with performing ethnic Hungarianness in various ways, kinship idioms evoke more stringent attachments, longer-lasting and robust over time. Ágnes and Tamás gave account of these tensions and ambivalences in the following words:

Tamás: Godparents of Michaela [Regina's sister] try their best to support their goddaughter, however, she is much more shy...

Ágnes: And now, that she went to a Romanian language secondary school, this relation might fade away...

T: Surely, it will be ended soon, this relationship. However, I think, if our Regina would not study in Hungarian any longer, we would still try hard to maintain our relationship. And I think it would survive after all.

Secondly, apart from shaping the content and forms of helping and temporalities of godparental relations, familial and kinship idioms may also imply the birth of new knowledges. National identities and categorisations may become understood and interpreted in their complex interrelations with material and social resources, constraints and possibilities in Moldavian Csángó communities. In the following extract, Edit, a middle-aged librarian in Budapest, and an active organiser in the programme reveals the dynamics of such changes, implied by parenting responsibilities and kinship metaphors. She confesses the cathartic drama of her goddaughter Petra choosing Romanian language secondary education in Moldavia (instead of Hungarian language education).

In my life, there was a huge change, when my goddaughter chose a Romanian language school, instead of a Hungarian. (...) I had to go through this shock. Finally I could pay proper attention. I called Marika, her mother, and we discussed the issue, and decided to accept what she [the goddaughter] has chosen. (...) I do not wish for another godchild, she has been and will be my goddaughter for a lifetime. And this strong emotional connection, we managed to preserve it. (...) They are so far away, and the mobile phone is the only way to talk, which is a bit expensive, so these inner struggles around the issue happened in my soul, and in my family, sometimes in tense quarrels. Whatever comes, she will remain in our family (...).

The trauma of choosing Romanian language schooling breaks the norms of the philanthropic programme. However, in line with wider expectations on attachment of parents and intimacy and dedication to children (Lawler 1999; Allen, 2005) a state of 'proper attention' on the part of the godmother Edit is achieved, familial ties are maintained, Petra 'will remain in the family'. On the other hand, the moral resolution of such normbreaking results in the birth of new knowledges and new meanings not only about an individual recipient, but on a collective level, about the supported community. Attempts to understand individual rationalities behind Petra choosing Romanian language education, local social structures, structural constraints and mobility perspectives also become visible, as well as deep disruptions between these lifeworlds and imaginaries of the philanthropic programme. An intensive emotional engagement and an empathetic attunement has far reaching consequences regarding the perceptions and representations of the recipients and their lifeworld, as expressed by Edit in the following way: 
(...) And we thought it through, about their environment, the way they live. In that village there is only agriculture, Petra's father is guestworker abroad, so he can earn money for the family. Families are broken, women doing men's work, and raising kids. Kids' duties are not only learning in school, but working in agriculture. The only point for breaking out from this environment is to study. And most schools are in Romanian language, (...) and they can easily cope in Romanian when looking for work in nearby towns, (...) or when becoming guestworkers in Italy or Germany.

Instead of heroic defenders of the Hungarian nation, culture and identities, recipients of the programme become, for Edit, everyday people fighting for a living and a better life. Instead of perspectives idealising these communities as guardians of (national) authenticity, recipient perspectives for social mobility, the constraints and potentials, and personal desires of studying and working become dominant.

\section{Discussion and Conclusions}

The present paper aimed to analyse entanglements between the often separately conceptualised domains of philanthropy and kinship. It proposed, more specifically, a systematic analysis of the phenomenon of 'philanthropic kinning' that is of philanthropic helping intertwined with creating personal connections of family and kin between donors and recipients. In line with earlier research the paper has shown how idioms of kinship may become important elements in contextualising abstract ideas of philanthropic support. The paper explored how the 'ordinary ethics' of kinship (Rabbitts, 2012) and more specifically parenting allows for the construction of philanthropic relations, either rendering them socially meaningful in cases when ideas of philanthropic and humanitarian helping are incomprehensible for potential participants (as in Bornstein, 2012); or filling abstract ideas of philanthropic helping with specific practical ways of feeling, thinking and acting (as in Rabbitts, 2012; Raithelhuber, 2019). Moreover, the paper elaborated further such modes of contextualisation: answering to calls to unearth the operation of power at the heart of donor-recipient personal relations (Fechter, 2019, 2020), it explored hierarchic roles, dispositions, expectations and identities that became enhanced by specific idioms of family and kinship.

These tasks were accomplished by focusing on a specific form of philanthropy, based on the ideology of responsibilities towards Hungarian co-ethnic minorities abroad, that is philanthropy initiated from Hungary towards ethnic
Hungarian minorities, with the mission of supporting them in the preservation of national culture and identities. Placing a programme in the centre of analysis that connects communities divergent in their comprehension and acceptance of the philanthropic mission-related in this case to the Hungarian national discourses -, enabled to show how familial and kinship idioms contribute to the creation and everyday operation of helping. First, on the side of the donors, it revealed how resonating with the idea of the nation (Yuval-Davis, 2005) kinship idioms close the gap between abstract ideas of philanthropic helping and the intent of creating actual donor-recipient relations. Second, on the side of recipients, it also revealed how it made- to a certain extent-philanthropic support socially meaningful for people and communities unfamiliar or hostile with national ideologies of authenticity operating in the background of the philanthropic programme.

Inquiring on the ways family, parenting and kinship idioms are embedded into donor-recipient philanthropic relations and interactions, the paper also pointed out how such 'kinning' contributes to reshaping the philanthropic process: how it evokes ideas, goals, values, identities, dispositions and practices diverging from the initial ideological framework of the philanthropic programme. While (god)parental roles of national socialisation resonate closely with national ideologies present in the mission of the programme, parental responsibilities of supporting education and employability of kids, first, and the quest for fun, joy and intimacy with the children, second, allowed for thinking beyond the initial philanthropic goals of preserving Hungarian national language, culture and community.

Such reshaping of philanthropic goals and practices also affected inequalities, power and knowledge production in philanthropic donor-recipient relations. It was shown above how godparent roles and practices of national socialisation may imply epistemic violence, causing frustration for godchildren and the entire recipient family, in cases when godparents disregard diverging concerns of national identification. Godparental focus on education, development and employability of godchildren, while disciplinary, were found to be more legitimate in the eyes of kids and/or their parents, and may provide a common ground and a common cause in the familial relations evoked in the philanthropic programme. The (god)parental quest for intimacy with godchildren, and the desire to bring fun and joy for them carries the greatest potentials for interactions to become oriented by the recipients of the philanthropic support, and thus for giving godchildren and their families voice and agency.

Feminist and postcolonial critiques of kinship idioms in philanthropy, humanitarianism or civic aid rapidly conclude that the (Western middle-class) desires to help unavoidably lead to various forms of domination 
articulating through each other (here familial relations of paternalism and national ideologies), resulting in the reinforcement and crystallisation of power hierarchies (for example Aflaki \& Freise, 2019; Burman, 1994; Grubb, 2021; Zarzycka, 2016). The present article shows that such claims may be foregone conclusions needing further elaboration and refinement. The multiplicity of parenting modes and ideals ('scripts') in the explored programme of philanthropic godparenthood opened up a space of manoeuvre regarding practices, meanings and power relations in donor-recipient interactions and relationships. Specifically, modes and ideals of parenting allowed for the actions and perspectives of recipients to orient and lead the helping process in various ways.

Furthermore, the paper demonstrates that neither disciplining nor love and care follow straight from the mere existence of personal donor-recipient contacts and the use of family metaphors. Complex patterns of care and control are enabled by specific organisational and discoursive components: by historically and socially varying meanings assigned to kinship terms, and specifically to parental responsibilities and obligations.

These explorations helped us complement recent research on hybridisation processes related to philanthropy, volunteering, humanitarianism, and the third or NGO sector at large. Recent studies already underlined the significance of the state and the market in such hybridisation (Shachar et al., 2019; Lichtermann \& Eliasoph, 2014). By demonstrating how kinship in philanthropy may become a powerful mediator between donor and recipient perspectives, this paper foregrounded the entanglements of philanthropy with yet another domain; and explored kinship with its multiple capacities in creating and maintaining such helping relationships.

Concerning the relevance of our descriptions for the broader field of philanthropy, I deny the peculiarity of this case. While the present paper is based upon a case study of a single civic programme, earlier research (Zakariás, 2015, 2019; Zakariás \& Feischmidt, 2020) has found a wide array of philanthropic and voluntary initiatives targeting ethnic Hungarian children in minority that incubate such processes. The production of care and intimacy is closely intertwined with mobilising concepts of kinship in 'twin-school' based voluntary programs, ubiquitous in the Hungarian public education since the postsocialist transition, linking schools, teachers, students and their families in Hungary and in ethnic Hungarian minority communities in Slovakia, Ukraine, Romania or Serbia. In these programmes that place personal donor-recipient relations in the centre, familial connotations and ideas of kinship between donors and recipients pop up frequently. Apart from the notion of godparenthood, 'mother-child' metaphors, as well as peer-group relations of becoming 'siblings' may appear in donors' as well as recipients' accounts. Such kinship metaphors, in turn, contribute to further enhancing caring dispositions, practices and temporalities in these philanthropic relationships, and shape in various ways knowledge and national ideologies of Hungarianness in the background of these programmes.

Moreover, this paper may have potentials for further generalisations. Although the current research, by unearthing the operation of national ideologies as linked to philanthropy, may seem to speak primarily to the field of nationalism studies, it also carries compelling messages beyond this scientific domain. It emphasises how philanthropy invite and evoke various moral frameworks and ideologies, beyond bare donor-recipient relations. Layered upon each other, these ideologies may simultaneously provide the moral foundations of donor and recipient roles, emotions, identities and motivations, and may orient practices of offering and accepting support. Accordingly, research cited in the theoretical section, addressing the operation of familial and kinship metaphors in philanthropy reveal a multiplicity of such conceptual frameworks and ideologies, beyond the national: global humanitarianism, transnational development or-for refugee godparenthood-the ideology of migrant integration all provide moral frameworks that are orchestrated in parallel and as related to familial moralities, concepts, metaphors. The call for a systematic elaboration on interacting effects of familial idioms, ideological and moral frameworks and the institutional context of philanthropy, formulated by this paper, may well be relevant in the above mentioned contexts as well, indeed diverse and heterogenous.

As a last remark, it must be stated that the phenomena analysed in this paper is far from unique in yet another sense: family metaphors and idioms of kinship may play a central role in the social construction and organisation of philanthropy in various ways. Such metaphors may be central, inter alia, in defining the recipients of philanthropic support, as for example the frequent case of support for families in material and economic disadvantage; or in defining the needs that must be helped and the helping activities, such as in case of offering professional parenting support through NGOs (de Koning et al., 2020). Family metaphors and idioms of kinship, furthermore, may also induce helping motivations based on donor's familial roles and identities, conceived as similar to potential recipients'such empathetic identification, based on shared motherhood has been explored in milk donation philanthropy (Oreg \& Appe, 2020, Oreg \& Appe, 2021). Within this broad and diverse array, our present study focuses on a specific subset of phenomena, that is on philanthropy that addresses previously unrelated donors and recipients as members of the same family, thus creating direct familial connections between them. Although family and kinship 
identities, roles, dispositions and practices of participants might be evoked and mobilised in all of the above cases, this paper assumes that such roles and identities would be most crystallised in the last set of philanthropic programmes. Such direct and explicit bonding of donors and recipients allowed us to explore hybridisation in its most pronounced and clear-cut forms-the relevance and generalisability of our conclusions to a broader palette of programmes linking philanthropy to familial metaphors, however, needs further systematic analysis.

Acknowledgements The author wishes to thank anonymous reviewers for their insights and suggestions. A first version of the paper was presented at the workshop Mobilities and Care. Transformations of belonging and inequalities, 5th Vienna Ethnography Lab, 2nd-4th of July 2020. The author also wishes to thank Domonkos Sik and Cecília Kovai for their support.

Funding Open access funding provided by Centre for Social Sciences. This paper received support from the Institute for Advanced Study, Central European University, Budapest-Vienna and from the NKFIH Research Grant: Solidarity in Late Modernity.

\section{Declarations}

Conflict of interest The author has no conflicts of interest to declare that are relevant to the content of this article.

Informed Consent Informed consent of research participants has been assured during data collection.

Open Access This article is licensed under a Creative Commons Attribution 4.0 International License, which permits use, sharing, adaptation, distribution and reproduction in any medium or format, as long as you give appropriate credit to the original author(s) and the source, provide a link to the Creative Commons licence, and indicate if changes were made. The images or other third party material in this article are included in the article's Creative Commons licence, unless indicated otherwise in a credit line to the material. If material is not included in the article's Creative Commons licence and your intended use is not permitted by statutory regulation or exceeds the permitted use, you will need to obtain permission directly from the copyright holder. To view a copy of this licence, visit http://creativecommons. org/licenses/by/4.0/.

\section{References}

Aflaki, I., \& Freise, M. (2019). Challenging the welfare system and forcing policy innovation? Unaccompanied asylum-seeking children in Sweden and Germany. The Journal of Refugee Studies, 34, 264-284. https://doi.org/10.1093/jrs/fez036

Allen, A. (2005). Feminism and motherhood in Western Europe, 1890-1970: The maternal dilemma. Springer.

Appe, S., \& Oreg, A. (2020). Lost and found in upstate New York: Exploring the motivations of "lost boys" refugees as founders of international nonprofit organizations. Administration \& Society, 52(8), 1209-1238.

Bárdi, N. (2013). Different images of the future of the Hungarian communities in neighbouring countries, 1989-2012. European Review, 21, 530-552.
Bodó, C., \& Lajos, V. (2020). Research on the language revitalization processes of the Moldavian Csángós. Knowledge interpreted with different stakeholders, participation and engagement (in Hungarian). Korunk, 3(9), 42-50.

Bodó, Cs., \& Zabolai, M. (2016). A csángó mürokon és a keresztanya: Nem és nemzet a moldvai magyar nyelv revitalizációs programjában. Társadalmi Nemek Tudománya, 6(1), 159-180.

Boltanski, L. (1999). Distant suffering, morality, media and politics. Cambridge University Press.

Bornstein, E. (2001). Child sponsorship, evangelism, and belonging in the work of World Vision Zimbabwe. American Ethnologist, $28(3), 595-622$.

Bornstein, E. (2012). Disquieting gifts: Humanitarianism in New Delhi. Stanford University Press.

Brusdal, R., \& Frønes, I. (2013). The purchase of moral positions: An essay on the markets of concerned parenting. International Journal of Consumer Studies, 37, 159-164. https://doi.org/10. 1111/j.1470-6431.2012.01094.x

Burman, E. (1994). Innocents abroad: Western fantasies of childhood and the iconography of emergencies. Disasters, 18, 238-253.

Burman, E. (2016). Deconstructing developmental psychology. Taylor \& Francis.

Carlsen, H. B., Doerr, N., \& Toubøl, J. (2020). Inequality in interaction: Equalising the helper-recipient relationship in the refugee solidarity movement. VOLUNTAS: International Journal of Voluntary and Nonprofit Organizations. https://doi.org/10. 1007/s11266-020-00268-9

de Koning, A., Johansen, M.-L., \& Marchesi, M. (2020). Introduction special issue "Paradoxical orders Parenting encounters, the welfare state, and difference in Europe." Ethnography, 1, 5. https://doi.org/10.1177/1466138120919448

Drążkiewicz, E. (2020). Institutionalised dreams: The art of managing foreign aid. Berghahn Books.

Dromi, S. M. (2021). Donor identity, morality, and nonprofit organizations: soliciting donations and recruiting volunteers for the Red Cross, 1863-1919. Nonprofit and Voluntary Sector Quarterly. August 2021.

Eriksen, T. H. (1991). The cultural contexts of ethnic differences. Man, 26(1), 127-144.

Faircloth, C. (2014). Intensive parenting and the expansion of parenting. In E. Lee, J. Bristow, C. Faircloth, \& J. Macvarish (Eds.), Parenting culture studies. Palgrave Macmillan. https:// doi.org/10.1057/9781137304612_2

Fechter, A. M. (2019). Development and the search for connection. Third World Quarterly, 40(10), 1816-1831.

Fechter, A. M. (2020). Brokering transnational flows of care: The case of citizen aid. Ethnos, 85(2), 293-308.

Feischmidt, M. (2005). The localization of Hungarian discourses on authenticity to Transylvania. (in Hungarian). In M. Feischmidt (Ed.), Deconstructing Transylvania, Ethnographic Museum (pp. 5-28). University of Pécs.

Flanigan, S. T. (2017). Crowdfunding and diaspora philanthropy: An integration of the literature and major concepts. VOLUNTAS: International Journal of Voluntary and Nonprofit Organizations, $28,492-509$.

Fretwell, N. (2020). The new educational pastorate: Link workers, pastoral power and the pedagogicalisation of parenting. Genealogy, 4, 37. https://doi.org/10.3390/genealogy4020037

Grubb, A. (2021). Avoiding intimacy-An ethnographic study of beneficent boundaries in virtual voluntary social work. VOLUNTAS: International Journal of Voluntary and Nonprofit Organizations. https://doi.org/10.1007/s11266-021-00350-w

Holzberg, B. (2019). Affective borders: The emotional politics of the German 'refugee crisis'. PhD thesis, The London School of Economics and Political Science (LSE). https://doi.org/10.1177/ 089976408701600104. 
Howell, S. L. (2006). The kinning of foreigners: Transnational adoption in a global perspective. Berghahn Books.

Kovai, M. (2016). Psychology and public policy. Psych sciences in Hungarian State Socialism 1945-1970 (in Hungarian). L'Harmattan.

Kvale, S. (1996). Interviews. An introduction to qualitative research interviewing. Sage.

Laihonen, P., Bodó, Cs., Heltai, J., \& Fazakas, N. (2020). The Moldavian Csángós: the Hungarian speaking linguistic minority in North-Eastern Romania. Linguistic Minorities in Europe Online. De Gruyter Mouton. https://www.degruyter.com/data base/LME/entry/lme.12543347/html. Accessed 15 November 2021.

Lakoff, G. (1995). Metaphor, morality, and politics, or, why conservatives have left liberals in the dust. Social Research, 62(2), 177-214

Lawler, S. (1999). Children need but mothers only want: The power of 'needs talk' in the constitution of childhood. In J. Seymour \& P. Bagguley (Eds.), Relating intimacies explorations in sociology (pp. 64-88). Palgrave Macmillan.

Lee, E., Bristow, J., Faircloth, C., \& Macvarish, J. (2014). Parenting culture studies. Basingstoke: Palgrave Macmillan.

Lichterman, P., \& Eliasoph, N. (2014). Civic action. American Journal of Sociology, 120(3), 798-863. https://doi.org/10.1086/ 679189

Malkki, L. (2015). The need to help: The domestic arts of international humanitarianism. Duke University Press.

Manzo, K. (2008). Imaging humanitarianism: NGO identity and the iconography of childhood. Antipode, 40, 632-657.

Marcus, G. E. (1995). Ethnography in/of the world system: The emergence of multi-sited ethnography. Annual Review of Anthropology, 24, 95-117.

Molpeceres, M., Pinazo, S., \& Aliena, R. (2012). Older Adult mentors and youth at risk: Challenges for intergenerational mentoring programs in family-centered cultures. Journal of Intergenerational Relationships, 10(3), 261-275.

Musick, M., \& Wilson, J. (2008). Volunteers: A social profile. Indiana University Press.

Noh, J. E. (2019). Human rights-based child sponsorship: A case study of ActionAid. VOLUNTAS: International Journal of Voluntary and Nonprofit Organizations, 30, 1420-1432.

Oreg, A., \& Appe, S. (2020). "Ain't no hood like motherhood": The complexity of human milk donor identity. Social Science Quarterly, 101(2), 439-458.

Oreg, A., \& Appe, S. (2021). Why is human milk donation absent from the literature on philanthropic giving? The invisible female donor and her invisible gift. Nonprofit and Voluntary Sector Quarterly. https://doi.org/10.1177/08997640211013907

Peti, L., \& Tánczos, V. (2012). Language, use, attitudes, strategies. Linguistic identity and ethnicity in the Moldavian Csángo Villages. Editura ISPMN.

Peti, L. (2011). Wearied respondents. The structure of saving the Csángós and its effects on their identity building strategies. In A. Barszczewska \& P. Lehel (Eds.), Integrating minorities: Traditional communities and modernization (pp. 243-267). RIRNM.

Rabbitts, F. (2012). Child sponsorship, ordinary ethics and the geographies of charity. Geoforum, 43(5), 926-936.

Raithelhuber, E. (2019). Turning into a "Godparent". How adult volunteers negotiate their personal life to become a mentor for "Unaccompanied Refugee Minors." Social Work and Social Welfare, 1(1), 23-36.

Rebollo, J. G., Escribano, C. P., et al. (2018). Charities as symbolic families: Ethnographic evidence from Spain. Journal of
Organizational Ethnography. https://doi.org/10.1108/JOE-032018-0012

Rose, N. (1999). Governing the soul-The shaping of the private self. Free Association Books.

Scheibelhofer, P. (2019). Gender and intimate solidarity in refugeesponsorships of unaccompanied young men. In M. Feischmidt, L. Pries, \& C. Cantat (Eds.), Refugee protection and civil society in Europe (pp. 193-220). Palgrave Macmillan.

Schwabenland, C. (2006). Stories, Visions and values in voluntary organisations. Ashgate.

Shachar, Y., von Essen, J., \& Hustinx, L. (2019). Opening up the "Black Box" of "Volunteering." Administrative Theory \& Praxis, 41(3), 245-265. https://doi.org/10.1080/10841806.2019. 1621660

Shirinian, T. (2018). The nation-family: Intimate encounters and genealogical perversion in Armenia. American Ethnologist, 45, $48-59$.

Sinervo, A., \& Cheney, K. (2019). NGO economies of affect: Humanitarianism and childhood in contemporary and historical perspective. In K. Cheney \& A. Sinervo (Eds.), Disadvantaged childhoods and humanitarian intervention, Palgrave studies on children and development (pp. 1-35). Palgrave Macmillan.

Suski, L. (2009). Children, suffering and the humanitarian appeal. In R. A. Wilson \& R. D. Brown (Eds.), Humanitarianism and suffering: The mobilization of empathy (pp. 202-222). Cambridge University Press.

Szőke, A. (2020). «Bons parents» et «enfants bien-aimés»: Parentalité intensive et pratiques quotidiennes dans les services d'aide à l'enfance en Hongrie. Lien Social Et Politiques, 85, 108-127. https://doi.org/10.7202/1073744ar

Thelen, T., Thiemann, A., \& Roth, D. (2014). State kinning and kinning the state in Serbian elder care programs. Social Analysis, 58(3), 107-123.

Thelen, T. (2015). Care as social organization: Creating, maintaining and dissolving significant relations. Anthropological Theory, 15(4), 497-515.

Timaru, C. (2020). The child is given by god and he takes care of him: Customs and beliefs related to birth and to Baptism in Pustiana (in Hungarian). Korunk, 31(9), 77-97.

Vasile, M., Cash, J. R., \& Heady, P. (2018). Contemporary godparenthood in central and eastern Europe: Introduction. Journal of Family History, 43(1), 3-11.

Vasile, M., Cash, J. R., \& Heady, P. (2018). Contemporary godparenthood in central and eastern Europe: Introduction. Journal of Family History, 43(1), 3-11.

Wuthnow, R. (1995). Learning to Care: Elementary Kindness in an Age of Indifference. New York: Oxford University Press.

Yin, R. K. (2014). Case study research design and methods (5th ed.). Sage.

Yuval-Davis, N. (2005). Gender \& Nation. Sage.

Zakariás, I. (2015). The production of solidarity: A case study of voluntary school programs of ethnic kin support. In K. Jochen \& Y. Albrecht (Eds.), Die Ambivalenz der Gefühle: Über die verbindende und widersprüchliche Sozialität von Emotionen (pp. 145-169). VS Verlag für Sozialwissenschaften.

Zakariás, I. (2019). Othering and recognition: National ideologies in donor-recipient encounters in Hungarian co-ethnic philanthropy. Revue Européenne Des Migrations Internationales, 35(1-2), 215-237.

Zakariás, I., \& Feischmidt, M. (2020). Producing the nation through philanthropy: Legitimising coethnic and prorefugee civic action in Hungary. Nations and Nationalism, 26, 1015-1032. https:// doi.org/10.1111/nana.12607 
Zarzycka, M. (2016). Save the child: Photographed faces and affective transactions in NGO child sponsoring programs. European Journal of Women's Studies, 23(1), 28-42.

Zelizer, V. (1985). Pricing the priceless child: The changing social value of children. Basic Books.
Publisher's Note Springer Nature remains neutral with regard to jurisdictional claims in published maps and institutional affiliations. 